\title{
Analisis Pengaruh Kualitas Auditor, Likuditas, Profitabilitas dan Solvabilitas terhadap Opini audit Going Concern pada Perusahaan Manufaktur yang Terdaftar di Bursa Efek Indonesia Tahun 2018-2020
}

\author{
Endrian Zalogo ${ }^{1)}$, Yunus Putra Duho ${ }^{2)}$, Arie Pratania Putri ${ }^{\left.{ }^{*}\right)}$ \\ Universitas Prima, Medan Indonesia \\ arieprataniaputri@unprimdn.ac.id
}

*Penulis Korespondensi

Diajukan : 26 Januari 2022

Disetujui : 9 Februari 2022

Dipublikasi : 10 Februari 2022

\begin{abstract}
The purpose of this study was to determine whether the quality of auditors, liquidity, profitability and solvency affect going concern opinions on manufacturing companies listed on the Indonesia Stock Exchange. This type of research is descriptive to understand the characteristics of some variables in certain situations. The data used is secondary data. The population of this survey is 62 manufacturing companies between 2018 and 2020. The sample was extracted using a targeted sampling procedure from a total of 30 companies. Data analysis used descriptive statistical analysis and logistic regression with SPSS 22. The results of logistic regression analysis showed that Auditor Quality had no effect on going concern audit opinion, while liquidity, profitability and solvency had an effect and significant on going concern audit opinion acceptance. The results of the t-test indicate that the significant value of auditor quality on audit opinion is $0.965>005$ and the t-count value is $0.44<t$-table value of 1.989 shows auditor quality has no effect and is not significant. The results of the t test show that the significant value of liquidity on the audit opinion is $0.030<0.05$ and the $t$ value is $2.222>$ the t table value is 1.989 . The results of the t-test indicate that the significant value of profitability on audit opinion is $0.000<0.05$ and the $t$-count value is $4.283>$ the t-table value is 1.989. The results of the $t$-test indicate that the significant value of solvency on the audit opinion is $0.000<0.05$ and the t-count value is $6.862>$ the t-table value is 1.989 . The results of logistic regression analysis show that Auditor Quality has no effect on going concern audit opinion, while liquidity, profitability and solvency have a significant and significant effect on going concern audit opinion acceptance.
\end{abstract}

Keywords: Auditor quality, liquidity, profitability, solvency audit opinion going Concern

\section{PENDAHULUAN}

Banyaknya manipulasi data keuangan dalam perusahaan besar, seperti kebangkrutan Enron Energy milik Lehman Brothers, bank investasi terbesar di Amerika Serikat, merupakan contoh kegagalan auditor AS. Sebuah negara yang mengevaluasi kemampuan perusahaan untuk menjaga kelangsungan bisnis. Pada tahun sebelum kebangkrutan, perusahaan menerima laporan audit wajar tanpa pengecualian. Kesalahan dalam mengeluarkan laporan audit dilakukan oleh salah satu Kantor Akuntan public yaitu, Arthur Andersen dan KAP Ernst \& Young Young yang ikut terlibat dan telah berhenti beroperasi. Kasus serupa pernah terjadi di Indonesia, termasuk PT Kimia Farma Tbk, yang terjerat kasus hukum karena telah memanipulasi laporan keuangan tahunan. Dengan 
kata lain, laporan keuangan tahunan yang disajikan tidak mencerminkan keadaan yang sebenarnya. Auditor harus bertanggung jawab untuk menilai apakah terdapat kecurigaan material tentang kemampuan perusahaan untuk mempertahankan kelangsungan usahanya dalam waktu hingga satu tahun sejak tanggal audit atas laporan keuangan tahunan. Jika ada keraguan tentang kelangsungan hidup perusahaan nirlaba, auditor harus mengungkapkannya dalam sertifikat audit wajar tanpa pengecualian dengan deskripsi.

Selain pentingnya kualitas auditor dalam menganalisis laporan keuangan, kualitas dari laporan keuangan itu sendiri sangat diperlukan. Laporan keuangan dibuat untuk memberikan gambaran umum atau laporan kemajuan perusahaan secara berkala. Laporan keuangan juga dapat menjadi acuan untuk melihat kondisi keuangan dapat juga digunakan dalam menentukan kinerja perusahaan (Rahmah \& Komariah, 2016). Ini dibuat oleh manajemen yang relevan dalam menyampaikan informasi keuangan kepada pihak luar. Tujuan utama laporan keuangan adalah untuk menyediakan informasi yang berguna bagi pengambilan keputusan bisnis dan ekonomi. Laporan keuangan harus berkualitas tinggi agar dapat memberikan informasi yang bermanfaat. Laporan keuangan sangat penting untuk audit auditor karena dibandingkan atau disesuaikan dengan catatan akuntansi oleh akuntan independen dari manajemen perusahaan. Setelah melakukan investigasi dengan menggunakan standar dan prosedur audit normal, auditor akan memastikan bahwa laporan tersebut mematuhi prinsip akuntansi normal mengenai kecukupan laporan keuangan tahunan perusahaan (neraca dan laporan laba rugi), atau setiap tahun. SA Section 341 menyatakan bahwa auditor juga bertanggung jawab untuk menilai kemampuan perusahaan dalam mempertahankan kelangsungan hidupnya (going concern) untuk jangka waktu tidak lebih dari satu tahun sejak tanggal laporan audit. Laporan kelangsungan usaha yang diterima dari perusahaan mengungkapkan keraguan auditor tentang kelangsungan hidup perusahaan. Salah satu pertimbangan yang harus diperhatikan auditor dalam memberikan opini kelangsungan usaha adalah untuk memprediksi apakah perusahaan akan bangkrut. Asumsi kelangsungan usaha adalah salah satu asumsi yang digunakan untuk melaporkan operasional dan entitas keuangan bahwa perusahaan memiliki kemampuan untuk mempertahankan profitabilitas selama satu tahun sejak tanggal laporan keuangan. Penelaahan atas opini audit tentang kelangsungan hidup perusahaan dapat didasarkan pada faktor-faktor seperti kualitas auditor, likuiditas, solvabilitas, dan profitabilitas. Likuiditas suatu perusahaan sering ditunjukkan dengan indikator lancar yang membandingkan aktiva lancar dengan kewajiban lancar. Semakin tinggi rasio lancar, semakin baik perusahaan mampu memenuhi kewajiban jangka pendeknya.

Profitabilitas adalah kemampuan perusahaan untuk mendapatkan keuntungan dari penjual, total aset, dan modal. Profitabilitas dapat diukur dengan Operating Profit Margin (OPM), yaitu rasio laba bersih sebelum pajak dibagi dengan penjualan bersih. Semakin besar rasio, semakin baik profitabilitas perusahaan, dan auditor tidak dapat meragukan kemampuan kelangsungan usaha untuk bertahan dan mengurangi kemungkinan pendapat kelangsungan usaha. Alasan peneliti memilih manufaktur sebagai subjek penelitian adalah karena industri manufaktur Bursa Efek Indonesia (BEI) terdiri dari berbagai subsektor sektor Property untuk mencerminkan reaksi pasar modal secara keseluruhan. Perusahaan manufaktur ini juga memiliki jumlah perusahaan terbesar di Bursa Efek Indonesia (BEI). Kami memilih perusahaan manufaktur untuk penyelidikan kami karena fakta ibahwa kasus perusahaan manufaktur lebih dominan daripada perusahaan lain, sesuai dengan fakta yang disebutkan. Dengan pemikiran tersebut, peneliti termotivasi untuk mengkaji kembali faktor-faktor yang mempengaruhi opini audit atas kelangsungan usaha. Penelitian ini 
hanya mempertimbangkan empat faktor: kualitas auditor, likuiditas, isolvabilitas, dan profitabilitas.

Penelitian ini menguji pengaruh kualitas auditor, likuiditas, profitabilitas, dan solvabilitas terhadap penerimaan laporan audit going concern. Penelitian ini merupakan replikasi dari penelitian yang dilakukan oleh Sutra Melania (Melania et al., 2016) yang meneliti tentang analisis dampak kualitas auditor, likuiditas, profitabilitas, solvabilitas, dan ukuran perusahaan terhadap opini audit suatu perusahaan terhadap kelangsungan usaha. Bedanya, penelitian Komalasari menggunakan data akhir tahun periode 2009-2013, sedangkan penelitian ini menggunakan laporan tahunan 2018-2020. Berdasarkan hal di atas, penulis-penulis tertarik untuk melakukan penelitian yang berjudul "Analisis Pengaruh Kualitas Auditor, Likuiditas, Profitabilitas Dan Solvabilitas Terhadap Opini Audit Going Concern Pada Perusahaan Manufaktur Yang Terdaftar Di Bursa Efek Indonesia".

\section{STUDI LITERATUR}

\section{Pengaruh Kualitas Auditor terhadap Opini Audit Going Concern}

Menurut Kharismatuti (Kharismatuti, 2021), kualitas audit adalah kemampuan seorang auditor untuk menemukan dan melaporkan suatu pelanggaran dalam sistem akuntansi klien berdasarkan standar auditing yang telah ditetapkan. Kemungkinan pendeteksian dapat dipengaruhi oleh fakta-fakta yang terkait dengan audit yang dilakukan oleh auditor untuk menghasilkan laporan audit. Isu yang terkait dengan pertanyaan audit adalah kompetensi auditor, persyaratan yang terkait dengan pelaksanaan audit, dan persyaratan. Menurut Kharismatuti (Kharismatuti, 2021), kualitas audit adalah kemampuan seorang auditor untuk menemukan dan melaporkan suatu pelanggaran dalam sistem akuntansi klien berdasarkan standar auditing yang telah ditetapkan. Kemungkinan pendeteksian dapat dipengaruhi oleh fakta-fakta yang terkait dengan audit yang dilakukan oleh auditor untuk menghasilkan laporan audit. Isu yang terkait dengan pertanyaan audit adalah kompetensi auditor, persyaratan yang iterkait dengan pelaksanaan audit, dan persyaratan.

H1 : Kualitas auditor berpengaruh positif terhadap penerimaan opini audit dengan going concern (GCAR)

\section{Pengaruh Likuiditas terhadap Opini Audit Going Concern}

Sutra Melania (2016) kemampuan perusahaan untuk membayar kewajiban jangka pendeknya dengan aset lancarnya. Dalam hal likuiditas, semakin sedikit likuid suatu perusahaan, semakin sedikit likuid yang dibayarkan perusahaan kepada krediturnya. Auditor dapat mengomentari asumsi kelangsungan hidup seluruh aset dibanding kesimpulan audit. Semakin rendah likuiditas, semakin banyak kredit yang bermasalah. Laporan audit harus mencakup informasi tentang kelanjutan kegiatan bisnis, dan sebaliknya, semakin likuid suatu perusahaan, semakin banyak dana yang dapat diperoleh dalam melunasi kewajiban tepat waktu dalam jangka pendek.

H2 : Likuiditas berpengaruh negatif terhadap penerimaan opini audit dengan going concern (GCAR)

\section{Pengaruh Profitabilitas terhadap Opini Audit Going Concern}

Minanari (Minanari, 2018) menyatakan bahwa profitabilitas adalah kemampuan suatu perusahaan untuk menghasilkan keuntungan atau laba. Jorenza (Jorenza et al., 2015) menjelaskan 
bahwa profitabilitas adalah kemampuan perusahaan untuk menghasilkan keuntungan dalam hal penjualan total aset dan modal ekuitas. Tujuan analisis ini juga untuk mengetahui keterkaitan antar pos-pos dalam neraca perusahaan untuk memberikan berbagai indikator yang iberguna untuk mengukur efisiensi dan profitabilitas suatu perusahaan, serta memperoleh laba atau rugi dari total aset. Ratio ini digunakan untuk menentukan profitabilitas manajemen dan efisiensi perusahaan secara keseluruhan. Semakin tinggi ROA maka semakin efektif pengelolaan aset perusahaan. Semakin tinggi tingkat pengembalian, semakin baik kinerja perusahaan, dan auditor tidak tidak mengeluarkan laporan opini going concern perusahaan yang labanya tinggi.

Sutra Melania (Melania et al., 2016) menemukan bukti bahwa profitabilitas berdampak negatif terhadap pemberian opini audit going concern. Perusahaan yang mempunyai rasio profitabilitas itinggi, maka perusahaan bisa mempertahankan perusahaannya di masa mendatang, sehingga auditor tidak akan memberikan opini audit going concern kepada perusahaan yang memiliki laba tinggi. Berdasarkan kesimpulan di atas maka dapat dibuat hipotesis sebagai berikut: H3 : Profitabilitas berpengaruh negatif terhadap penerimaan opini audit dengan going concern (GCAR)

\section{Pengaruh Solvabilitas terhadap Opini Audit Going Concern}

Rasio solvabilitas merupakan rasio yang dapat mengukur sejauh mana kemampuan perusahaan memenuhi kewajiban keuangannya. Solvabilitas mengacu pada jumlah uang yang dihasilkan dari hutang perusahaan ke aset. Rasio solvabilitas yang tinggi dapat berdampak buruk pada posisi keuangan perusahaan. Rasio solvabilitas yang tinggi dapat menunjukkan kinerja keuangan perusahaan yang buruk dan dapat menimbulkan ketidak pastian dalam profitabilitas perusahaan. Akibatnya, perusahaan lebih cenderung menerima laporan audit daripada going concern.

Penelitian Grace (Grace et al., 2019)Solvabilitas adalah kemampuan perusahaan untuk memenuhi biaya bunga dan membayar kembali kewajiban ijangka panjang sesuai dengan jadwal pembayaran yang digunakan. Berdasarkan penjelasan diatas, maka dapat dibuat hipotesis sebagai berikut:

H4 : Solvabilitas berpengaruh positif terhadap penerimaan opini audit dengan going concern (GCAR)

\section{Kerangka konseptual}

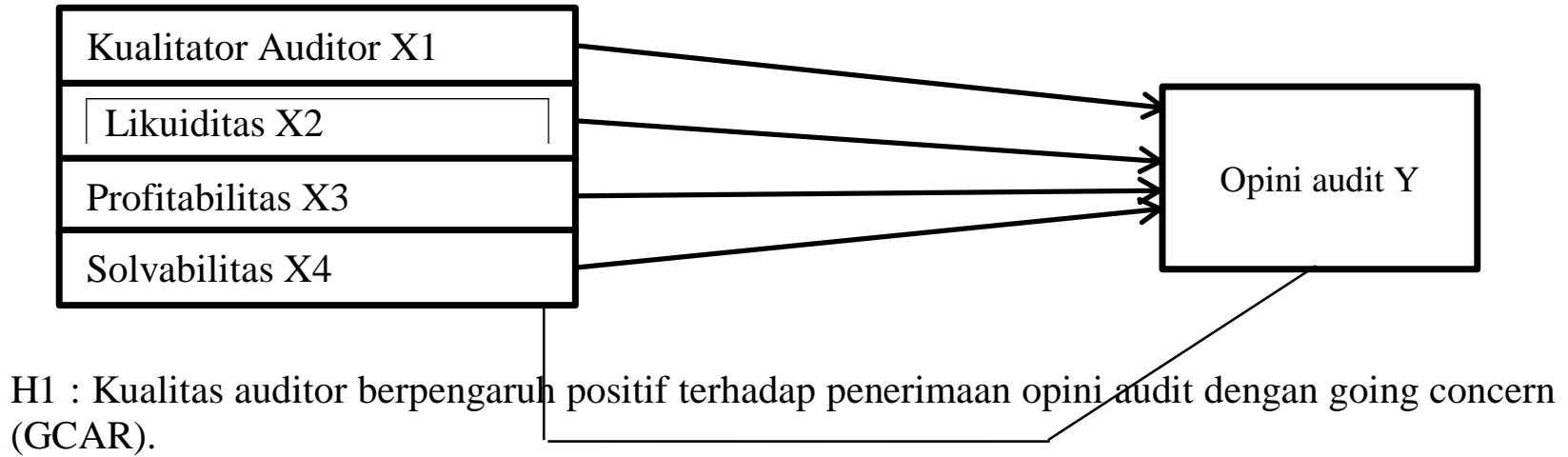

(GCAR). 
H2 : Likuiditas berpengaruh negatif terhadap penerimaan opini audit dengan going concern (GCAR)

H3 : Profitabilitas berpengaruh negatif terhadap penerimaan opini audit dengan going concern (GCAR).

H4 : Solvabilitas berpengaruh positif terhadap penerimaan opini audit dengan going concern (GCAR)

\section{Jenis Penelitian}

\section{METODE}

Jenis penelitian adalah deskriptif untuk memahami karakteristik beberapa variabel dalam situasi tertentu.

\section{Pendekatan Penelitian}

Pendekatan penelitian yang digunakan dalam survei ini adalah survei deskriptif dan diartikan sebagai pengumpulan masalah berupa fakta-fakta terkini dari populasi. Dengan kata lain, penelitian deskriptif adalah jenis penelitian yang bertujuan untuk memberikan gambaran yang komprehensif tentang lingkungan sosial, atau untuk mempelajari dan memperjelas suatu fenomena atau kenyataan sosial dengan menggunakan beberapa variabel yang terkait dengan masalah, yang merupakan penelitian deskriptif. Satuan investigasi antar fenomena yang akan diuji.

\section{Populasi dan Sampel}

Populasi adalah wilayah generalisasi yang terdiri dari objek/subyek dengan kualitas dan karakteristik tertentu yang ditentukan oleh penelitian untuk mempelajarinya dan menarik kesimpulan darinya. Menurut Penlitian Risma Dwi Komala \& Nellyaningsih, (Komala \& Nellyaningsih, 2017) sampel adalah bagian dari jumlah dan karakteristik populasi. Sampel diambil dari perusahaan manufaktur yang terdapat disector Property yang terdaftar di Bursa Efek Indonesia (BEI).

\section{Variabel Dependen (Y)}

Variabel dependen adalah jenis variabel yang dijelaskan atau dipengaruhi oleh variabel bebas. Variabel terikat dalam penelitian ini adalah opini kelangsungan usaha perusahaan. Variabel opini audit going concern diukur dengan menggunakan variabel dummy. Kategori 1 mewakili perusahaan manufaktur yang menerima laporan audit Wajar Tanpa Pengecualian untuk kelanjutan kegiatan usaha, dan 0 mewakili perusahaan manufaktur yang tidak menerima laporan audit Wajar Tanpa Pengecualian untuk kelanjutan kegiatan usaha.

\section{Variabel Independen $(\mathrm{X})$}

Variable independen (bebas) merupakan variabel yang mempengaruhi variabel terikat. Variabel terikat sebagai berikut :

\section{Kualitas Uditor $(X I)$}

Penelitian kualitas auditor diukur dengan menggunakan ukuran Kantor Akuntan Publik (KAP) yang menggunakan variabel dummy. apabila KAP tergolong dalam kategori The Big Four Auditors, akan diberi kode 1, sedangkan jika tidak termasuk kategori The Big Four Auditors, akan diberi kode 0. KAP The Big Four terdiri dari (Melania et al., 2016): 
KAP BIG FOUR DI INDONESIA

\begin{tabular}{|l|l|}
\hline Haryanto Sahari \& Rekan & Price Weterhous-Cooper \\
\hline $\begin{array}{l}\text { Purwantono, Sarwoko \& } \\
\text { Sandjaja }\end{array}$ & Ernest \&Young \\
\hline Osman Bing Satrio \& Rekan & Deloitte Touche \& Tohmatsu \\
\hline Sidharta, Sidharta \& Widjaja & KPMG \\
\hline
\end{tabular}

\section{Likuiditas (X2)}

Digunakan karena rasio ini mengukur kemampuan perusahaan di dalam memenuhi kewajiban-kewajiban yang akan jatuh tempo (Melania et al., 2016). Sebagai parameter dari rasio likuiditas, penulis menggunakan Current Ratioyang dirumuskan sebagai berikut :

$$
C R=\frac{\text { Aktiva Lancar }}{\text { Hutang Lancar }}
$$

\section{Profitabitias $(X 3)$}

Penulis menggunakan metode analisis profitabilitas karena masyarakat pada umumnya percaya bahwa pengukuran kinerja dan efektivitas didasarkan pada profitabilitas yang dicapai oleh perusahaan. (Kasmir, 2014) Profitabilitas dalam penelitian menggunakan ROA yang dirumuskan sebagai berikut:

$$
\text { Roa }=\frac{\text { Laba bersih }}{\text { Total Aseet }}
$$

\section{Solvabilitas $(X 4)$}

Solvabilitas adalah ukuran kemampuan perusahaan untuk memenuhi biaya bunga dan membayar hutang jangka panjang sesuai dengan jadwal pembayaran (Grace et al., 2019). Rasio tersebut adalah Debt to Total Asset Ratio sebagai berikut :

$$
\text { DAR }=\frac{\text { Lotal Kewajiban }}{\text { Total Aseet }}
$$

\section{Analisis Data}

Penelitian ini menggunakan pendekatan kuantitatif dan menggunakan data sekunder dari produsen yang terdaftar di Bursa Efek Indonesia (BEI) dari tahun 2018 hingga 2020. Metode analisis yang digunakan dalam penelitian ini adalah statistik deskriptif menggunakan regresi logistik dengan menggunakan persamaan berikut (Melania et al., 2016).

Keterangan :

$$
\operatorname{Ln} \frac{G C}{1-G C}=\beta 0+\beta 1(\text { AuQua t })+\beta 2(\text { CRt }+\beta 3(\text { ROAt })+\beta 4(\text { DARAt })+\mathbf{\varepsilon t}
$$

$\operatorname{Ln} \frac{G C}{1-G C}=$ Opini Auditor

$\beta=$ Intersep 
AuQua = Kualitas Auditor

$\mathrm{CR}=$ Current Ratio

$\mathrm{ROA}=$ Return on Assets

DAR $=$ Debt to Assets Ratio

$\beta 1-4=$ Koefisien Masing masig Variabel

$\varepsilon \mathrm{t}=$ Error Perusahan pada tahun $\mathrm{t}$

\section{1) Pengujian Hipotesis Secara Simultan (Uji F)}

Pengujian ini dilakukan dengan tujuan untuk mengetahui pengaruh antara variabel terikat dan variabel bebas (Nanincova, 2019). Dengan criteria yaitu:

Bila "Fhitung $<$ Ftabel maka Ho diterima dan Ha ditolak, pada $\alpha=0,05$ "

Bila "Fhitung $>$ Ftabel maka Ho ditolak dan Ha diterima, pada $\alpha=0,05$

2) Secara Parsial (Uji t)

Pengujian t digunakan menguji variabel terikat dengan variabel bebas secara parsial dapat saling memberikan pengaruh satu antara lain (Nanincova, 2019). Dengan criteria yaitu :

Bila $t$ hitung < t tabel, Ho diterima dan Ha ditolak, pada $\alpha=0,05$

Bila $\mathrm{t}$ hitung $>\mathrm{t}$ tabel, Ho ditolak dan Ha diterima, pada $\alpha=0,05$

HASIL

\section{Statistik Deskriptif}

Statistik deskriptif dipergunakan untuk memberikan gambaran rata-rata suatu hasil survei, standar deviasi (standar ideviasi), dan data dalam bentuk nilai minimum dan maksimum. Jumlah variabel bebas dan terikat adalah 90 data. Hasil statistik deskriptif penelitian ini dapat dilihat pada table berikut :

Tabel 1. Statistik Deskriptif

Descriptive statistics

\begin{tabular}{|l|c|r|r|r|r|}
\hline & $\mathrm{N}$ & Minimum & Maximum & \multicolumn{1}{c|}{ Mean } & Std. Deviation \\
\hline Kualitas Auditor & 90 & .00 & 1.00 & .1111 & .31603 \\
\hline CR & 90 & .00 & 24.88 & 3.8577 & 4.48826 \\
\hline ROA & 90 & -9422.00 & 9960.00 & 1600.0778 & 4564.29066 \\
\hline DAR & 90 & .00 & 9600.00 & 4014.3123 & 2113.05656 \\
\hline Opini Audit & 90 & .00 & 1.00 & .9333 & .25084 \\
\hline Valid N (listwise) & 90 & & & & \\
\hline
\end{tabular}

Sumber : Hasil Output SPSS Statistic 22

Tabel di atas menunjukkan bahwa 80 perusahaan telah mendapatkan opini going concern dan 10 perusahaan telah diaudit oleh KAP, Kantor Akuntan Big Four.

a. Kualitas Auditor

Kualitas auditor adalah kemungkinan bahwa auditor akan menemukan dan melaporkan pelanggaran sistem akuntansi klien berdasarkan standar audit yang ditetapkan. Berdasarkan 3.1 bahwa nilai minimum 0.00 sedangkan nilai maksimum 1.00 mendapatkan nilai rata-rata 0.1111serta std. Devation 0.31603. menunjukan bahwa kualitas audit tidak memenuhi standar yang ditetapkan. 


\section{b. Likuiditas}

Likuiditas merupakan indikator kemampuan perusahaan dalam menggunakan modal kerja untuk memenuhi hutang jangka pendeknya. Berdasarkan tabel 3.1 dijelaskan bahwa nilai minimum sebesar 0.00 dimiliki PT. Bumi Citra Permai Tbk 2018, PT. Cowell Development Tbk 2019,2020, PT. Capri Nusa Satu Properti Tbk 2020, PT. Bakrieland Development Tbk 2020, PT. Forza Land Indonesia Tbk 2020, sedangkan nilai maximum 24.88 dimiliki oleh PT. Bekasi Asri Pemula Tbk 2019. Nilai Rata-Rata sebesar 3.8577 serta std. Devation 4.48826 menunjukkan bahwa rata-rata perusahaan mampu memenuhi kewajiban jangka pendeknya yang dimilikinya.

\section{c. Profitabilitas}

Profitabilitas adalah ukuran seberapa besar perusahaan menghasilkan keuntungan. Profitabilitas dapat diukur dengan menggunakan Rasio Return on Assets (ROA). Table 3.1 dijelaskan bahwa nilai minimum -9422.00 dimiliki oleh Gading Development Tbk 2020, sedangkan nilai maximum 9960.00 dimiliki oleh Jaya Real Property Tbk 2018, nilai rata-rata 1600.0778 serta std. Devation 4564.29066 menunjukkan bahwa rata-rata perusahaan sampel masih mampu menghasilkan laba demi kelangsungan usahanya.

\section{d. Solvabilitas}

Solvabilitas merupakan alat ukur yang menunjukkan seberapa besar aset yang dibiayai oleh dana kreditur. Solvabilitas pada penelitian ini Debt to Total Asset Ratio (DAR). Nilai minimum sebesar 0,00 pada table 3.1 dimiliki PT. Bumi Citra Permai Tbk 2018, PT. Cowell Development Tbk 2019, 2020, PT. Capri Nusa Satu Properti Tbk 2020, PT. Bakrieland Development Tbk 2020, PT. Forza Land Indonesia Tbk 2020, sedangkan maximum sebesar 9600.00 diperoleh Bhakting Agung Propertindo Tbk 2018 nilai rata-rata 4014.3123 serta std. Devation 2113.05656 menunjukkan bahwa perusahaan masih memperoleh pendanaan dari kreditur.

\section{Hasil uji asumsi klasik}

a. Uji normalitas

Memperlihatkan perbandingan data observasi yang berdistribusi normal melalui grafik histogram. Hasil pada gambar sebagai berikut: 


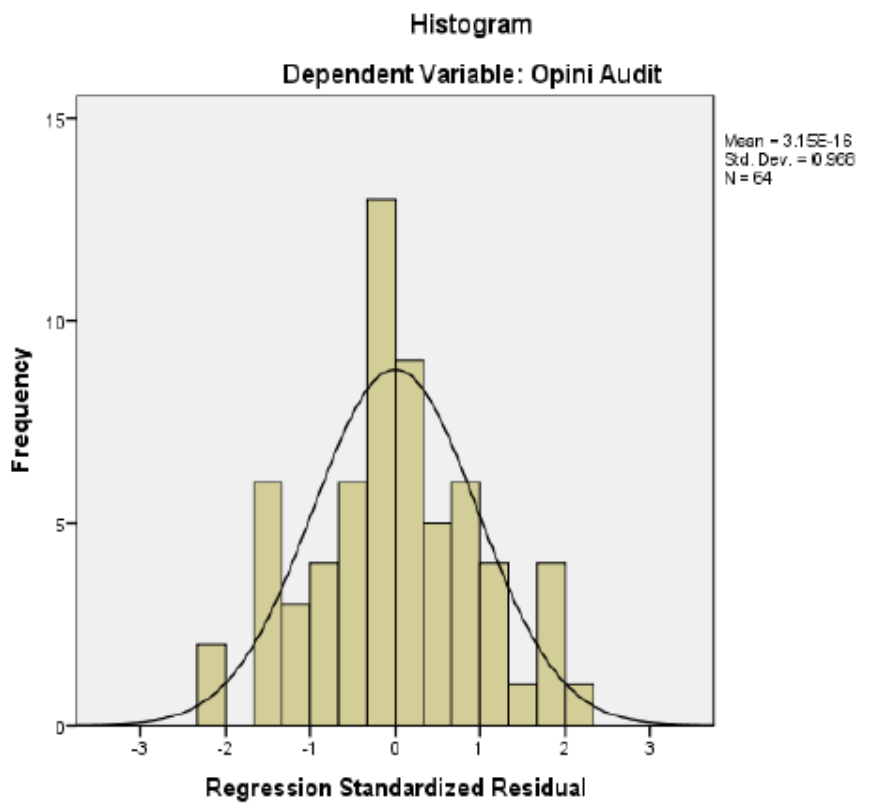

\section{Gambar 1. Grafik Histogram setelah transformasi SQRT}

B. Uji Statistik

Berikut hasil uji normalitas menggunakan Kolmogorov-smirnov One-Sample Kolmogorov-Smirnov Test

\begin{tabular}{|l|l|r|}
\hline \multicolumn{2}{|l|}{} & $\begin{array}{c}\text { Unstandardized } \\
\text { Residual }\end{array}$ \\
\hline $\mathrm{N}$ & & 90 \\
\hline Normal Parameters ${ }^{\mathrm{a}, \mathrm{b}}$ & Mean & .0000000 \\
\hline & Std. Deviation & .16959589 \\
\hline $\begin{array}{l}\text { Most Extreme } \\
\text { Differences }\end{array}$ & Absolute & .088 \\
\hline & & .088 \\
\hline & Positive & -.067 \\
\hline Kolmogorov-Smirnov Z & Negative & .088 \\
\hline Asymp. Sig. (2-tailed) & & $200^{\mathrm{c}, \mathrm{d}}$ \\
\hline
\end{tabular}

Sumber: Hasil Output SPSS Statistic 22

Berdasarkan Tabel 3.2 uji normalitas di atas dapat dilihat bahwa Asymp. Sig. i(2-tailed) sebesar .200 atau nilainya lebih besar dari 0,05 dapat disimpulkan bahwa data pada penelitian terdistribusi secara normal. 

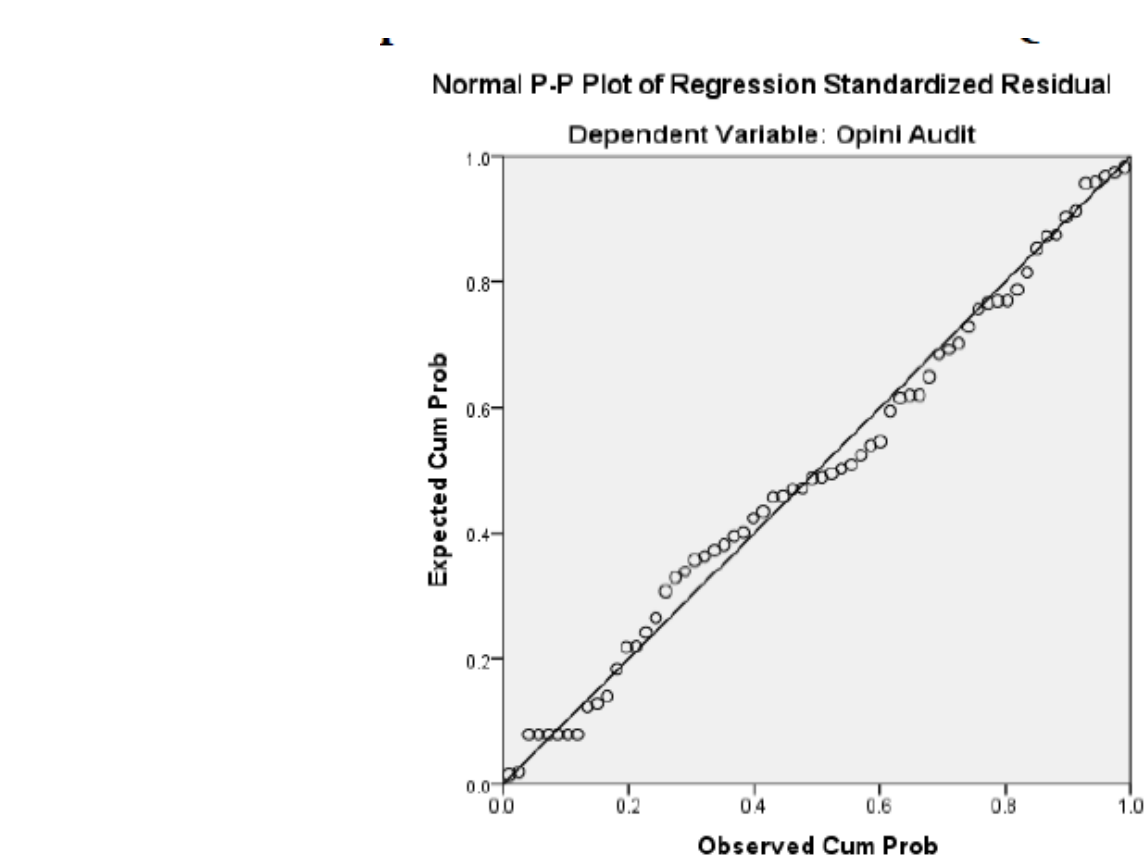

Sumber : Hasil Output SPSS Statistic 22

Gambar di atas menunjukan kumpulan dari titik yang mendekati garis diagonalnya. Artinya memenuhi asumsi normalitas.

\section{Hasil analisis data penelitian}

1) Model penelitian

Pengujian model ini memakai analisi regresi linear berganda.

Tabel 2. Persamaan Regresi Linear Berganda Coefficientsa

\begin{tabular}{|c|c|c|c|c|c|}
\hline \multirow{2}{*}{ Model } & \multicolumn{2}{|c|}{$\begin{array}{c}\text { Unstandardized } \\
\text { Coefficients }\end{array}$} & $\begin{array}{c}\text { Standardized } \\
\text { Coefficients }\end{array}$ & \multirow{2}{*}{ T } & Sig. \\
\cline { 2 - 4 } 1 & $\mathrm{~B}$ & Std. Error & Beta & T & \\
(Const & & & & \\
ant) & .204 & .052 & 3.884 & .000 \\
Kualitas & & & & & \\
Auditor & .003 & .065 & .003 & .044 & .965 \\
SQRT_X2 & .005 & .002 & .164 & 2.222 & .030 \\
SQRT_X3 & .004 & .001 & .337 & 4.283 & .000 \\
SQRT_X4 & .007 & .001 & .546 & 6.862 & .000 \\
\hline
\end{tabular}

Sumber : Hasil Output SPSS Statistic 22

Dengan menggunakan sqrt maka dapat diambil kesimpulan :

Opini audit =0,204 + 0,003 AuQua + 0,005 CR + 0,004ROA + 0,007 DAR

Keterangan: 
a Konstanta sebesar 0,204 satuan menjelaskan Kualitas auditor, current ration, return on assets dan Debt to Asset Ratio bernilai konstan maka Opini Audit 0,204.

b Koefisien regresi Kualitas Auditor dengan nilai 0,003 satuan menjelaskan bahwa pada tiaptiap kenaikan terjadi persatuan Kualitas Auditor dapat mengakibatkan adanya kenaikan 0,003 yang terjadi pada Opini Audit.

c Koefisien regresi Curren ration (CR) dengan nilai 0,005 satuan menjelaskan bahwa pada tiap-tiap kenaikan terjadi persatuan Curren ration (CR) dapat mengakibatkan adanya kenaikan 0,005 yang terjadi pada Opini Audit.

d Koefisien regresi return on assets (ROA) dengan nilai 0,004 satuan menjelaskan bahwa pada itiap-tiap kenaikan terjadi persatuan return on assets (ROA) dapat mengakibatkan adanya kenaikan 0,004 yang terjadi pada Opini Audit.

e Koefisien regresi Debt to Asset Ratio (DAR) dengan nilai 0,007 satuan menjelaskan bahwa pada tiap-tiap kenaikan terjadi persatuan Debt to Asset Ratio (DAR) dapat mengakibatkan adanya kenaikan 0,004 yang terjadi pada Opini Audit.

2) Koefisien determinasi hipotesis

\section{Tabel 3. Uji Koefisien Determinasi} Model Summary

\begin{tabular}{|c|c|c|c|c|}
\hline Model & $\mathbf{R}$ & R Square & Adjusted R Square & Std. Error of the Estimate \\
\hline 1 & $\mathbf{. 8 8 1}^{\mathbf{a}}$ & $\mathbf{. 7 7 5}$ & $\mathbf{7 6 0}$ & $\mathbf{. 1 4 3 9 0}$ \\
\hline
\end{tabular}

Sumber : Hasil Output SPSS Statistic 22

Dari output di atas dapat nilai nilai Adjuted R Square (keofisien determinasi) sebesar 0,760 yang artinya pengaruh variebel indepen $(\mathrm{X})$ terhadap variabel $(\mathrm{Y})$ sebesar $76 \%$.

3) Penguji hipotesis secara simultan (Uji iF)

Tabel 4. Simultan Transformasi SQRT

\begin{tabular}{|l|l|r|r|r|c|c|}
\hline \multicolumn{7}{|c|}{ ANOVA $^{\mathrm{a}}$} \\
\hline \multicolumn{2}{|l|}{ Model } & Sum of Squares & Df & Mean Square & F & Sig. \\
\hline 1 & Regression & 4.216 & 4 & 1.504 & 50.900 & $.000^{\mathrm{b}}$ \\
\hline & Residual & 1.222 & 59 & .021 & & \\
\hline & Total & 5.437 & 63 & & & \\
\hline
\end{tabular}

Sumber : Hasil Output SPSS Statistic 22

Dari tabel 3. 7 dapat diketahui nilai untuk pengaruh Kualitas auditor (X1), Current ration (X2), return on assets (x3) dan Debt to Asset Ratio (X4) terhadap Opini Audit (Y) adalah sebesar $0,000<0,05$ dan $\mathrm{F}$ hitung 50,900 > nilai $\mathrm{F}$ tabel 2,48. Hal tersebut membuktikan HO3 ditolak dan Ha3 diterima. Artinya terdapat pengaruh Kualitas auditor (X1), Current ratio (X2), return on assets (x3) dan Debt to Asset Ratio (X4) terhadap Opini Audit (Y) secara signifikan.

4) Pengujian hipotesis secara parsial

Tabel 5. Uji Parsial 


\begin{tabular}{|c|c|c|c|c|c|c|}
\hline \multicolumn{7}{|c|}{ Coefficients $^{\text {a }}$} \\
\hline \multirow{2}{*}{\multicolumn{2}{|c|}{ Model }} & \multicolumn{2}{|c|}{ Unstandardized Coefficients } & \multirow{2}{*}{$\begin{array}{c}\text { Standardized Coefficients } \\
\text { Beta }\end{array}$} & \multirow[b]{2}{*}{$\mathrm{T}$} & \multirow[b]{2}{*}{ Sig. } \\
\hline & & B & Std. Error & & & \\
\hline & (Constant) & .204 & .052 & & 3.884 & .000 \\
\hline & Kualitas Auditor & .003 & .065 & .003 & .044 & .965 \\
\hline & SQRT_X2 & .005 & .002 & .164 & 2.222 & .030 \\
\hline & SQRT_X3 & .004 & .001 & .337 & 4.283 & .000 \\
\hline & SQRT_X3 & .007 & .001 & .546 & 6.862 & .000 \\
\hline
\end{tabular}

Sumber : Hasil Output SPSS Statistic 22

Hasil tabel 5. sebagai berikut :

a Sesuai dengan tabel 3.8 yaitu hasil uji t (parsial) menunjukan bahwa nilai signifikan Kualitas auditor (X1) terhadap Opini audit (Y) adalah 0,965>005 dan nilai t hitung 0,44 $<$ nilai t tabel 1,989 menunjukan Kualitas auditor tidak berpengaruh dan tidak signifikan.

b Hasil uji t (parsial) menunjukan bahwa nilai signifikan Curren ration (X2) terhadap Opini Audit (y) adalah 0,030<0,05 dan nilai t hitung 2.222 > nilai t tabel 1,989 maka Ho1 ditolak dan Hal diterima. Artinya terdapat pengaruh Curren ration terhadap opini audit secara signifikan.

c Hasil uji t (parsial) menunjukan bahwa nilai signifikan return on assets (X3) terhadap Opini Audit (y) adalah 0,000 < 0,05 dan nilai t hitung $4.283>$ nilai t tabel 1,989 maka Ho1 ditolak dan Ha1 diterima. Artinya terdapat pengaruh return on assets tehadap opini audit secara signifikan.

d Hasil uji t (parsial) menunjukan bahwa nilai signifikan Debt to Asset Ratio (X4) terhadap Opini Audit (y) adalah 0,000 < 0,05 dan nilai t hitung 6.862 > nilai t tabel 1,989 maka Ho1 ditolak dan Hal diterima. Artinya terdapat pengaruh Debt to Asset Ratio tehadap opini audit secara signifikan.

\section{PEMBAHASAN}

\section{Pengaruh Kualitas Auditor terhadap Opini Audit Going Concern}

Hasil uji parsial didapatkan nilai signifikan Kualitas auditor (X1) terhadap Opini audit (Y) adalah 0,965 > 005 dan nilai t hitung 0,44 < nilai t tabel 1,989 menunjukan Kualitas auditor tidak berpengaruh dan tidak signifikan pada nilai perusahaan manufaktur yang terdaftar di bursa efek indonesia Tahun 2018-2020. Kualitas audit menurut Standar Profesional Akuntan Publik (SPAP) menyatakan bahwa pemeriksaan yang dilakukan oleh pemeriksa memenuhi syarat apabila memenuhi standar pemeriksaan dan pengendalian mutu. Dalam kasus kantor akuntansi. Mengaku sebagai KAP besar seperti perusahaan big four, mereka berusaha menjaga nama besaridan menghindari tindakan yang bisa membingungkan nama besar. Namun hasil reset ini tidak mempengaruhi penetapan pelanggaran sistem akuntansi berdasarkan standar auditing yang telah ditetapkan.

Pada hasil di atas sama pada dengan Penelitian sebelumnya Vita Mustika (Mustika et al., 2015) menyatakan bahwa kualitas audit tidak berpengaruh signifikan terhadap penerimaan Opini audit going concern. 


\section{Pengaruh Likuiditas terhadap Opini Audit Going Concern}

Hasil uji parsial didapatkan nilai signifikan Curren ration (X2) terhadap Opini Audit (y) adalah $0,030<0,05$ dan nilai $t$ hitung $2.222>$ nilai $\mathrm{t}$ tabel 1,989 maka artinya terdapat pengaruh Opini Audit secara signifikan pada perusahaan manufaktur yang terdaftar di bursa efek indonesia Tahun 2018-2020. Dalam hubungannya dengan opini audit going concern Semakin rendah likuiditas suatu perusahaan, semakin kecil kemampuan untuk melunasi hutang jangka pendek dari aset lancar, dan semakin banyak kredit bermasalah yang cenderung terjadi, yang dipertanyakan oleh auditor. Tentang kelangsungan membiarkan perusahaan muncul. Di sisi lain, semakin likuid suatu perusahaan, semakin mampu untuk memenuhi kewajiban jangka pendeknya tepat waktu.

Pada penelitian Christian Lie (Lie et al., 2016) yang menyatakan bahwa likuiditas perusahaan berpengaruh terhadap penerimaan opini audit going concern dari auditor .

\section{Pengaruh Profitabilitas terhadap Opini Audit Going Concern}

Hasil uji parsial didapatkan nilai signifikan return on assets (X3) terhadap Opini (y) adalah $0,000<0,05$ dan nilai thitung $4.283>$ nilai $t$ tabel 1,989. maka artinya terdapat pengaruh Opini Audit secara signifikan pada perusahaan manufaktur yang terdaftar di bursa efek indonesia Tahun 2018-2020. Profitabilitas adalah kemampuan perusahaan untuk menghasilkan laba dari semua aset yang tersedia. Hal ini dikarenakan auditor cenderung mengeluarkan laporan opini going concern untuk kelangsungan usaha jika perusahaan tidak mampu menghasilkan laba. Penelitian ini dapat memenuhi kemampuan untuk menghasilkan keuntungan atau profit dalam bisnis real estate.

Pada penelitian Norma Ayu Kartika \& Siti Khairani (Kartika \& Khairani, 2012)yang menyatakan bahwa Rasio likuiditas pada PT Indocement Tunggal Prakarsa Tbk dan PT Gresik (Persero) Tbk dari tahun 2007-2011 dapat dikatakan baik, sedangkan PT Holcim Tbk kurang baik. Rasio aktifitas ketiga industri semen tersebut dikatakan kurang baik. Rasio profitabilitas PT Holcim Tbk yang masih dikaterogikan jauh lebih baik.

\section{Pengaruh Solvabilitas terhadap Opini Audit Going Concern}

Hasil uji parsial didapatkan nilai signifikan Debt to Asset Ratio (X4) terhadap Opini Audit (y) adalah $0,000<0,05$ dan nilai t hitung $6.862>$ nilai t tabel 1,989 maka artinya terdapat pengaruh Opini Audit secara signifikan pada perusahaan manufaktur yang terdaftar di bursa efek indonesia Tahun 2018-2020. Solvabilitas merupakan rasio yang digunakan oleh kreditur untuk mengukur total aset perusahaan yang dibiayainya. Perusahaan yang memiliki hutang yang tinggi akan cenderung mengalami kesulitan keuangan. Hal ini secara tidak langsung akan mempertanyakan kemampuan auditor untuk mempertahankan kelangsungan hidupnya. Sebaliknya, jika pelarut perusahaan tidak memadai, risiko pembayaran utang dan bunga oleh perusahaan rendah, dan auditor tidak meragukan profitabilitas perusahaan.

Pada penelitian Christian Lie (Lie et al., 2016) membuktikan bahwa solvabilitas berpengaruh positif terhadap penerimaan penerimaan opini audit going concern.

\section{KESIMPULAN}

Kualitas auditor secara sebagian tidak mempunyai pengaruh dan tidak signifikansi terhadap opini audit going concern di perusahaan sektor Property yang sudah masuk pada Daftar Bursa Efek Indonesia Tahun 2018-2020. Likuiditas secara (parsial) mempunyai pengaruh penting terhadap opini audit going concern di perusahaan pada sektor Property yang telah masuk di daftar Bursa Efek Indonesia. Profitabilitas secara (parsial) mempunyai pengaruha dan signifikan terhadap 
opini audit going concern di perusahaan pada sektor Property 2018-2020 yang telah masuk di daftar Bursa Efek Indonesia. Profitabilitas secara sebagian (parsial) mempunyai pengaruha dan signifikan terhadap opini audit going concern di perusahaan pada sektor Property yang telah masuk di daftar Bursa Efek Indonesia. likuiditas, Profitabilitas, dan solvabilitas mempunyai pengaruh serta signifikansi secara simultan di perusahaan dengan sektor Property yang telah masuk di daftar Bursa Efek Indonesia.

\section{UCAPAN TERIMA KASIH}

Pada kesempatan ini penulis mengucapkan rasa terima kasih dan penghargaan yang setinggi-setingginya kepada yang terhormat Ibu Arie Pratania Putri, S.E., M.Si., Ak, CA., CJAT , sebagai Dosen Pembimbing atas kesudiannya memberikan bantuan dan bimbingan serta arahan untuk menyelesaikan penulisan jurnal ini ditengah-tengah kesibukannya.

\section{DAFTAR PUSTAKA}

Grace, D. P. R., Tinneke, M. T., \& Joula, J. R. (2019). Analisis Rasio Keuangan Untuk Menilai Kinerja Keuangan pada PT. Indonesia Prima Poperty Tbk Jakarta Pusat. Jurnal Administrasi Bisnis (JAB), 122-130. doi: https://doi.org/10.35797/jab.9.3.2019.25543.122-130

Jorenza, Chiquita, \& Sumati. (2015). ANALISIS PENGARUH KEPEMILIKAN MANAJERIAL, KEBIJAKAN HUTANG DAN PROFITABILITAS TERHADAP KEBIJAKAN DEVIDEN DAN NILAI PERUSAHAAN PADA PERUSAHAAN MANUFAKTUR DI BEI. Jurnal EMBA, 1141-1151.

Kartika, N. A., \& Khairani, S. (2012). Analisis Laporan Keuangan Pada Perusahaan Semen yang Terdaftar di Bursa Efek Indonesia. Artikel Publikasi.

Kasmir. (2014). Analisis Laporan Keuangan. Rajawali Pers.

Kharismatuti, N. (2021). PENGARUH KOMPETENSI DAN INDEPENDENSI TERHADAP KUALITAS AUDIT DENGAN AUDITOR SEBAGAI VARIABEL MODERASI. Universitas Diponogoro.

Komala, R. D., \& Nellyaningsih. (2017). TINJAUAN IMPLEMENTASI PERSONAL SELLING PADA PT. ASTRA INTERNASIONAL DAIHATSU ASTRA BIZ CENTER BANDUNG PADA TAHUN 2017. Jurnal Fakultas Ilmu Terapan Universitas Telkom, 3(2), 330-337.

Lie, C., Wardani, R. P., \& Pikir, T. W. (2016). Pengaruh Likuiditas, Solvabilitas, Profitabilitas, dan Rencana Manajemen terhadap Opini Audit Going Concern. Berkala Akuntansi Dan Keuangan Indonesia, 1, No. 2(2), 84-105.

Melania, S., Andini, R., \& Arifati, R. (2016). ANALISIS PENGARUH KUALITAS AUDITOR, LIKUIDITAS PROFITABILITAS, SOLVABILITAS DAN UKURAN PERUSAHAAN TERHADAP OPINI AUDIT GOING CONCERN PADA PERUSAHAAN MANUFAKTUR YANG TERDAFTAR DI BURSA EFEK INDONESIA. Journal of Accounting.

Minanari. (2018). PENGARUH PROFITABILITAS, MANAJEMEN LABA DAN KEBIJAKAN DEVIDEN TERHADAP NILAI PERUSAHAAN STUDI EMPIRIS PADA PERUSAHAAN MANUFAKTUR YANG TERDAFTAR DI BURSA EFEK INDONESIA PERIODE 20152016. Jurnal Provita, 139-149. 
Mustika, V., Hardi, \& Julita. (2015). PENGARUH KUALITAS AUDIT, DEBT DEFAULT, OPINION SHOPPING, DAN PERTUMBUHAN PERUSAHAAN TERHADAP PENERIMAAN OPINI AUDIT GOING CONCERN PADA PERUSAHAAN MANUFAKTUR (Yang Terdaftar DiBursa Efek Indonesia 2011-2015). Jurnal Online Mahasiwa, 4(1).

Nanincova, N. (2019). PENGARUH KUALITAS LAYANAN TERHADAP KEPUASAN PELANGGAN NOACH CAFE AND BISTRO. AGORA Jurnal Mahasiswa Manajemen Bisnis, 7(2).

Rahmah, M. N., \& Komariah, E. (2016). Analisis Laporan Keuangan Dalam Menilai Kinerja Keuangan Industri Semen Yang Terdaftar Di BEI. Jurnal Online Insan Akuntan, 1(1), 4358. 